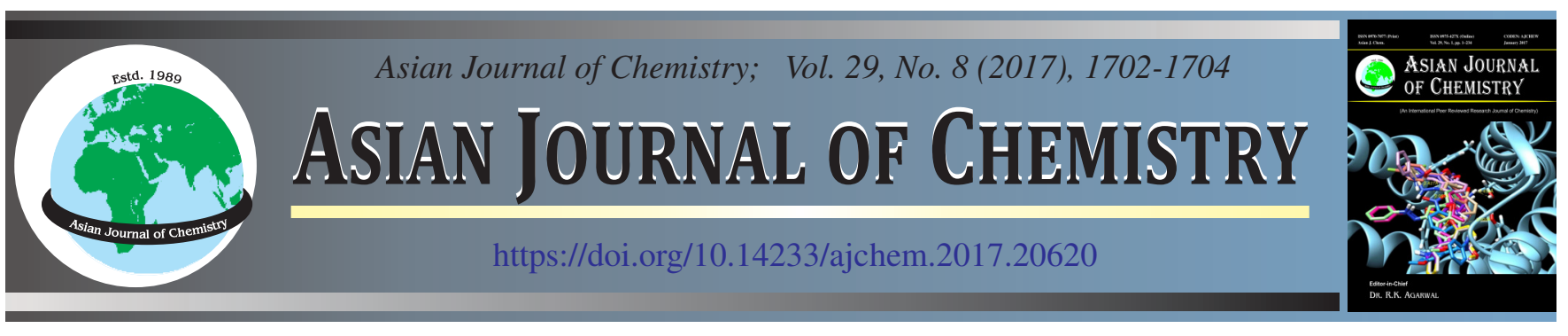

\title{
Characterization of Allophane from Gamalama Volcanic Soil, North Maluku, Indonesia
}

\author{
Indra Cipta ${ }^{1, *}$, Nur A. Limatahu ${ }^{1}$, St. Hayatun Nur Abu $^{1}$, Indriana Kartini $^{2}$ and Yateman Arryanto $^{2}$
}

${ }^{1}$ Department of Chemistry Education, Faculty of Teacher Training and Education, Khairun University, Ternate, Indonesia ${ }^{2}$ Department of Chemistry, Faculty of Mathematics and Natural Science, Universitas Gadjah Mada, Yogyakarta, Indonesia

*Corresponding author: E-mail: indra.chemy@gmail.com

\begin{abstract}
Extraction of allophane particles from Gamalama volcanic soil have been performed and characterized by using FTIR, XRD, SEM-EDX and TEM. Gamalama volcanic soil sample was dried in air for 5 days and crushed into 200 mesh particle size. The sample is then treated with $10 \% \mathrm{H}_{2} \mathrm{O}_{2}$ and dispered at $\mathrm{pH} 10$ by addition of $2 \mathrm{M} \mathrm{NaOH}$. Colloid layer about $10 \mathrm{~cm}$ from the surface of the solution was taken after decanted for 10-20 h. Allophane were collected by centrifuge. The FTIR spectra shows peaks which are vibration characteristic of alluminosilicate. X-ray diffraction result proved that allophane is non-crystalline aluminosilicate mineral. TEM result has confirmed that the resulted allophane is spherule with diameter about $4 \mathrm{~nm}$. The nature of allophane to form globular aggregates has confirmed by SEM. In the isolated allophane, $\mathrm{Si} / \mathrm{Al}$ ratio is 1.45 .
\end{abstract}

Keywords: Volcanic soil, Allophane, Non-crystalline, Aluminosilicate, Globular aggregates.

ᄂ - - - - - - - - - - - - - - - - - - - - - - - - - - - - - - - -

\section{INTRODUCTION}

North Maluku is a province in Indonesia in which there are five active volcanoes. The fifth of the volcano is Mount Gamalama in Ternate, Gamkonora in Halmahera Barat, Ibu and Dukono in North Halmahera and Kiebesi in South Halmahera. Mount Gamalama, which located adjacent to the Khairun University, Ternate, has erupted 60 times since 1538. The eruption has produced millions of tons of volcanic soil which contains a variety of very useful materials. One of the materials contained in the volcanic soil is allophane particles that are formed naturally in volcanic soil weathering processes $[1,2]$. The existence of allophane in the volcanic soil of Mount Gamalama has not been studied previously. This led to the use of volcanic soil of Mount Gamalama until now is limited to the agricultural sector or simply as an adsorbent pollutants. In this study, allophane from the volcanic soil of Mount Gamalama North Maluku was isolated and characterized by using FTIR, XRD, TEM and SEM-EDX. Allophane is a noncrystalline mineral aluminosilicate with $\mathrm{Si} / \mathrm{Al}$ ratio between 0.5-2 and 3.5-5.0 $\mathrm{nm}$ in particle size [3-5].

\section{EXPERIMENTAL}

Allophane extraction from the volcanic soil of Mount Gamalama was done by Henmi and Wada method [6] which modified in accordance with the availability of laboratory equipments. Gamalama volcanic soil sample was taken from
$30 \mathrm{~cm}$ depth and dried in air for 5 days, then crushed into 200 mesh particle size. The sample is then treated with $10 \% \mathrm{H}_{2} \mathrm{O}_{2}$ and dispered at $\mathrm{pH} 10$ by addition of $2 \mathrm{M} \mathrm{NaOH}$. The sample was then decanted for 10-20 h in room temperature. Colloid layer about $10 \mathrm{~cm}$ from the surface of the solution was taken for later coagulated by addition of $\mathrm{NaCl}$. The precipitate results from the sedimentation process were separated from the solution and then soaked in distilled water to remove $\mathrm{NaCl}$. As an indicator, $\mathrm{AgNO}_{3}$ was used to ensure aliquot that has been free from $\mathrm{NaCl}$. Furthermore, the fraction is then centrifuged. The last step in the extraction of allophane is drying process and characterized by FTIR, XRD, TEM and SEMEDX.

\section{RESULTS AND DISCUSSION}

Infrared spectroscopy method is a qualitative analysis to determine the functional groups contained in allophane. FTIR spectrum (Fig. 1) shows that the volcanic ash-soil have absorption peaks at wave numbers $3670.54,1867.09,1199.72$, 935.48 and $800.48 \mathrm{~cm}^{-1}$. Absorption peak $3670.54 \mathrm{~cm}^{-1}$ indicate the possibility of $\mathrm{OH}$ stretching vibration of $\mathrm{Si}-\mathrm{OH}$ or $\mathrm{Al}-\mathrm{OH}$. Absorption peak at $1199.72 \mathrm{~cm}^{-1}$ shows stretching of Si-O-Si [7]. Asymmetric stretching $\mathrm{Si}-\mathrm{O}-\mathrm{Si}$ showed at $935.48 \mathrm{~cm}^{-1}$, $800.48 \mathrm{~cm}^{-1}$ shows the symmetric vibration of Si-O-Si [8].

The FTIR spectra of allophane is showed $\mathrm{OH}$ stretching vibration moved to $3417 \mathrm{~cm}^{-1}$ may be due to the presence of Al-OH Gibbsitic sheet of allophane. Absorption at wave number 


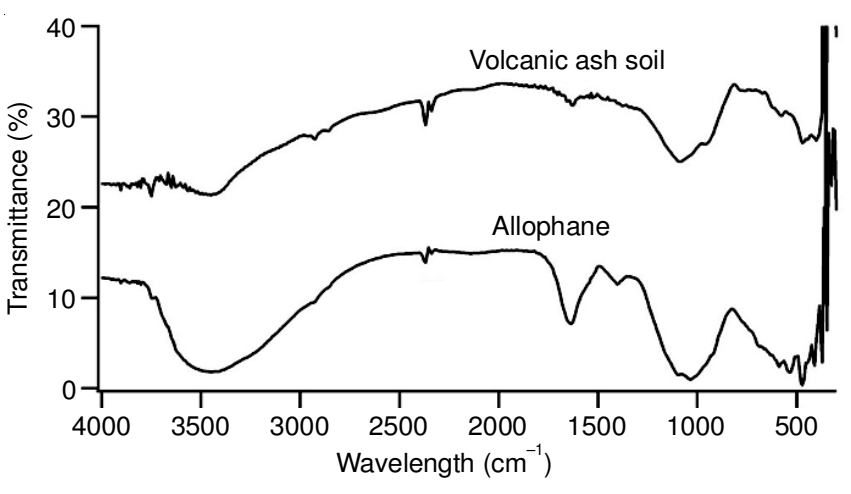

Fig. 1. Gamalama volcanic ash-soil and allophane FTIR spectra

$2368 \mathrm{~cm}^{-1}$ is characteristic of the presence of aliphatic organic compounds [4]. This peak is become weaker due to $\mathrm{H}_{2} \mathrm{O}_{2}$ treatment. The $\mathrm{OH}$ vibrations of water molecules those are still trapped within the framework of allophane is indicated by absorption at $1635 \mathrm{~cm}^{-1}$ [9]. Vibration at 1033,85 and 586 $\mathrm{cm}^{-1}$, respectively is an absorption for the $\mathrm{Si}-\mathrm{O}-\mathrm{Al}$ and $\mathrm{Si}-\mathrm{O}-$ $\mathrm{Al}$ in octahedral framework [10-12]. Absorption peak at 470,63 $\mathrm{cm}^{-1}$ which is absence in volcanic ash-soil, indicated peculiar wall structure of allophane ((HO) $\left.\mathrm{Si}(\mathrm{OAL})_{3}\right)$ [13].

X-ray diffraction of Gamalama volcanic ash-soil (Fig. 2) show peaks at $2 \theta=22.0145^{\circ}(d=4.03) ; 30.3588^{\circ}(d=2.94)$; $35.7163^{\circ}(\mathrm{d}=2.51)$, indicate cristobalite (JCPDS 11-695A). Peaks at $2 \theta=25.1761^{\circ}(d=3.53) ; 29.1288^{\circ}(d=3.06)$ for coesite (JCPDS 14-654). The highest intensity peak at $2 \theta=$ $27.9451^{\circ}(\mathrm{d}=3.18)$ is indicate the existence of albite (JCPDS IO-393). Those peaks are not shown in XRD of the allophane and indicates its extraction succesfully done. The XRD analysis of allophane shows the diffraction peaks at $2 \theta 27^{\circ}(0.33 \mathrm{~nm})$ and $38.9^{\circ}(0.23 \mathrm{~nm})$ which is identified as a properties of amorphous materials. Low peak at almost all angles, especially at $2 \theta 5.6^{\circ}-12^{\circ}(0.73$ to $1.5 \mathrm{~nm})$, showed low order in allophane samples that have been separated from the volcanic soil of Mount Gamalama. These results are in accordance with the facts that allophane is a non-crystalline aluminosilicate.

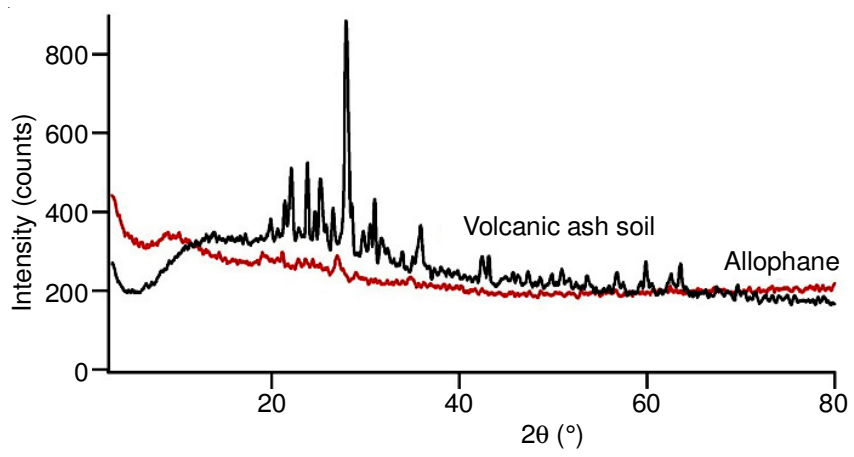

Fig. 2. XRD of Gamalama volcanic ash-soil and Allophane

Allophane particles are irregular spherule and tend to form porous nano size aggregates with a dimeter 3.5-5.0 nm [1416]. Characterization using TEM (Fig. 3a) confirmed irregular spherical structure of allophane with outer diameter is about $4 \mathrm{~nm}$. The allophane aggregate shaped like a ball with its diameter about $0.5 \mu \mathrm{m}$ or $500 \mathrm{~nm}$ shown in Fig. 3b. Maeda et al. [12] succesfully isolated allophane from pumice bed in
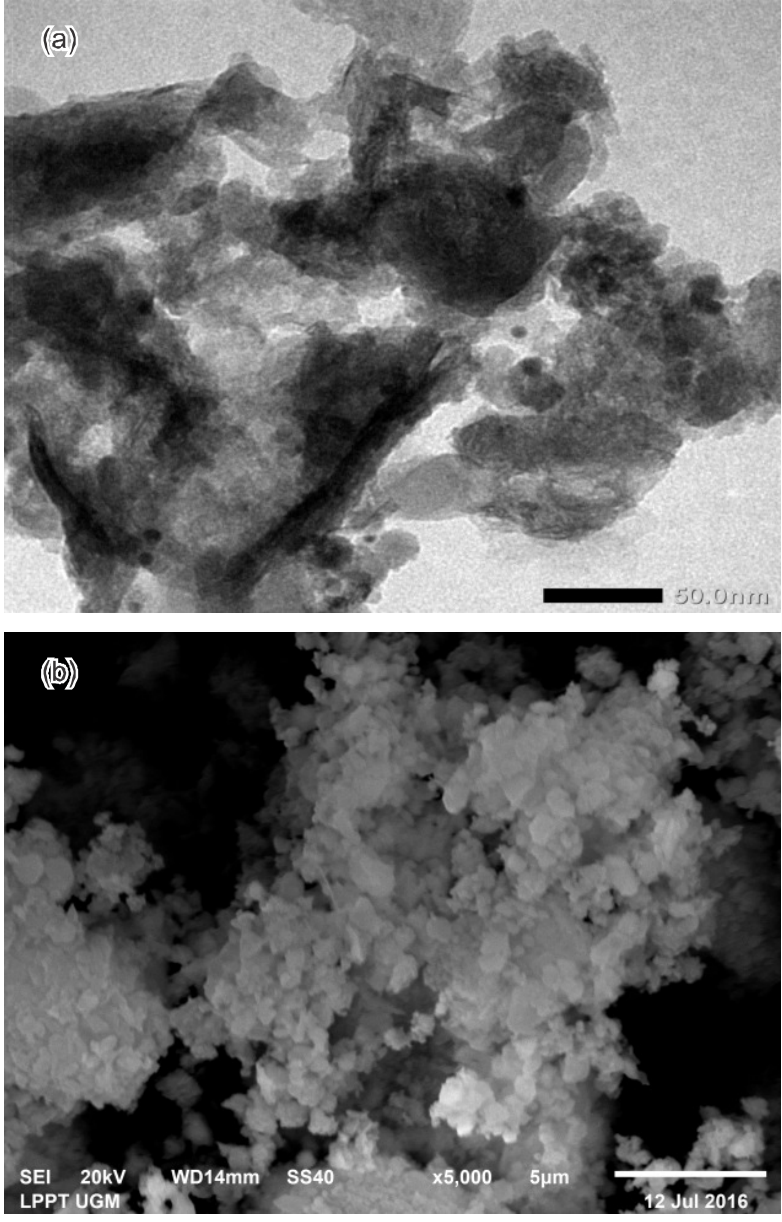

Fig. 3. Allophane image by (a) TEM characterization, (b) SEM characterization

Kanuma, obtained from Otsuka collection. The SEM micrograph of it, showed irregular spherule form with diameter about $300 \mathrm{~nm}$. Si/Al ratio of allophane of Gamalama volcanic soil is 1.45 and from EDX spectra contain impurities $9.53 \% \mathrm{Fe}$ (image not shown). Iyoda et al. [5] have found same result that the natural allophane from New Zealand also contain impurities such as Fe-minerals containing.

\section{Conclusion}

Gamalama volcanic soil has allophane potential that will support the developments of nano material research in North Maluku province. The resulted allophane that isolated from Gamalama volcanic soil is irregular spherule with outer diameter about $4 \mathrm{~nm}$ and $1.45 \mathrm{Si} / \mathrm{Al}$ ratio. Allophane globular aggregates has diameter about $0.5 \mu \mathrm{m}$.

\section{ACKNOWLEDGEMENTS}

This study was funded by Ministry of Research and Higher Education, Indonesia. The authors are grateful to Environment and Dasar Laboratory of Khairun University for the facilities.

\section{REFERENCES}

1. S.J. Klaine, P.J.J. Alvarez, G.E. Batley, T.F. Fernandes, R.D. Handy, D.Y. Lyon, S. Mahendra, M.J. McLaughlin and J.R. Lead, Environ. Toxicol. Chem., 27, 1825 (2008); https://doi.org/10.1897/08-090.1. 
2. G. Yuan, J. Environ. Sci. Health A, 39, 2545 (2004); https://doi.org/10.1081/ESE-200027009.

3. Z. Abidin, N. Matsue and T. Henmi, Clays Clay Miner, 55, 443 (2007); https://doi.org/10.1346/CCMN.2007.0550410.

4. M. Calabi-Floody, J.S. Bendall, A.A. Jara, M.E. Welland, B.K.G. Theng, C. Rumpel and M.L. Mora, Geoderma, 161, 159 (2011); https://doi.org/10.1016/j.geoderma.2010.12.013.

5. F. Iyoda, S. Hayashi, S. Arakawa, B. John, M. Okamoto, H. Hayashi and G. Yuan, Appl. Clay Sci., 56, 77 (2012); https://doi.org/10.1016/j.clay.2011.11.025.

6. T. Henmi and K. Wada, Am. Mineral., 61, 379 (1976).

7. Z. Haque, V. Ali and M. Husain, Optik, 124, 4287 (2013); https://doi.org/10.1016/j.ijleo.2013.01.043.

8. M.S. Khalil, L.A. Elkabee and B. Murphy, J. Colloid Interface Sci., 287, 534 (2005); https://doi.org/10.1016/j.jcis.2005.02.041.

9. L. Reinert, F. Ohashi, M. Kehal, J.-L. Bantignies, C. Goze-Bac and L. Duclaux, Appl. Clay Sci., 54, 274 (2011); https://doi.org/10.1016/j.clay.2011.10.002.
10. C. Kang, L. Jing, T. Guo, H. Cui, J. Zhou and H. Fu, J. Phys. Chem. C, 113, 1006 (2009); https://doi.org/10.1021/jp807552u.

11. J. Madejova, M. Janek, P. Komadel, H.J. Herbert and M.C. Moog, Appl. Clay Sci., 20, 255 (2002);

https://doi.org/10.1016/S0169-1317(01)00067-9.

12. H. Maeda, Y. Hashimoto and E.H. Ishida, Appl. Clay Sci., 44, 71 (2009); https://doi.org/10.1016/j.clay.2009.01.013.

13. R.L. Parfitt, Aust. J. Soil Res., 28, 343 (1990); https://doi.org/10.1071/SR9900343.

14. M.C. Floody, B.K.G. Theng and M.L. Mora, Clay Miner., 44, 161 (2009); https://doi.org/10.1180/claymin.2009.044.2.161.

15. B. Creton, D. Bougeard, K.S. Smirnov, J. Guilment and O. Poncelet, J. Phys. Chem. C, 112, 358 (2008);

https://doi.org/10.1021/jp0738412.

16. E.G. Garrido-Ramirez, B.K.G. Theng and M.L. Mora, Appl. Clay Sci., 47, 182 (2010); https://doi.org/10.1016/j.clay.2009.11.044. 